\title{
Examining the Performance of Islamic Banks in the Context of Bangladesh
}

\section{Ayesha Siddiqua}

Master of Business Administration (MBA), Department of Finance and Banking, Hajee Mohammad Danesh Science and Technology University, Dinajpur-5200, BANGLADESH

*Corresponding Contact:

Email: ayeshasiddiquakeya@gmail.com

\begin{abstract}
As a unique banking system Islamic Banking gained popularity all over the world. In 1983 Bangladesh also came forward with Islamic banking. This study focused on the performance of six selected Islamic banks in Bangladesh during 2011-2015. Researchers collected data from the annual reports of the Banks. Variables such as investment, total asset, deposit, earnings per share (EPS), return on asset (ROA) and return on equity (ROE) were selected for the study. In this study the main tools were growth and trend analysis. This empirical investigation revealed that the growth of total asset, deposit and investment was up to the mark but the Banks were not able to increase the growth rate of EPS, ROA and ROE. The result also showed that Islamic banks are doing good job in Bangladesh although the Banks are operating according to the conventional banking framework.
\end{abstract}

Key Words: Islamic banking, performance, growth, trend analysis

JEL Classification Code: G 21

\section{INTRODUCTION}

The Economic life of a nation mostly depends on the Banking sector of a country. Bangladesh is a rising economic country and both Conventional and Islamic Banks are running their business promptly in this country. This study seeks to evaluate the performance of Islamic banks in Bangladesh. Islamic banking system was introduced in Bangladesh by the establishment of Islami Bank Bangladesh Ltd. in 1983. Kabir et al. (2012) mentioned that other Islamic Banks and traditional banks are also culturing Islamic Shariah based banking by opening Islamic banking wings following the footsteps of Islami Bank Bangladesh Ltd. According to Uddin (2014) Islamic banking activity that is compatible with the Shariah principles and its practical use by the development of Islamic economics. He concluded that all the Islamic banks of Bangladesh are able to obtain a stable growth and square of correlation coefficient is positive in most cases which indicate the prospect of Islamic banks is very bright in 
Bangladeshi context. Abduh et al. 2013 conducted a study on the efficiency and performance of Islamic banks in Bangladesh. They used ratio analysis to measure performance and data envelopment analysis to measure the efficiency of the banks. From the analysis they concluded that Shahjalal Islami Bank Limited. Perform better than other Islamic banks and all selected Islami Banks was on the growing stage during 2006 to 2010. Chakraborty et al. (2015) evaluated the performance of Islami Bank Bangladesh Limited. They found that productivity ratio, current ratio, quick ratio, profitability and solvency ratio were increasing which leads to performance efficiency of the bank. Ahsan (2016) conducted CAMEL rating analysis on the 3 selected Islamic Banks of Bangladesh and investigated that all the selected Islamic Banks were in strong position in performing the banking activities during 2007 to 2014 . Rashid and Nishat (2009) investigated the Islamic Banks of Bangladesh through financial ratios, common size income statement and balance sheet during the year 2001 to 2006. They stated that the performance of Islamic Banks was poor as there were some problems in Islamic Banking system such as lack of efficient workforce, lack of marketing and direct Islamic Banking law from government and absence of Islamic capital and interbank markets. Islam and Salim (2011) examined the operational efficiency of Bangladeshi Islamic Banks during the period of 2004 to 2008 through ROA, ROE, net profit after tax, investment to deposit and total asset. From the study they concluded that Islamic banks were performing good job but there still a issue of conventional framework of banking prevailed in the country. Yousuf et al. (2014) examined the Islamic banking scenario in Bangladesh and concluded that most of the Islamic banks showed tremendous and notable growth in profitability in the last decades. They stated that these banks have significant contribution in the banking industry in Bangladesh. Akhter et al. (2011) investigated the Islamic banks in Pakistan to evaluate the efficiency and performance of Islamic banking of the country. They used nine financial ratios under profitability, efficiency and credit risk to determine the result. They used financial statements of the Banks for the financial year 2006 to 2010 as the source of secondary data and used trend analysis as the statistical tool. The result showed that the balance sheet had a good trend but there is no significant difference in the trend of income statement.

\section{Objective of the Study}

The main objective of the study is to examine the performance of Islamic banks using growth and trend analysis in Bangladesh.

\section{Materials AND Methods}

This study was carried out to examine the performance of the six selected Islamic Banks in Bangladesh for the year 2011-2015 considering the variables investment, total asset, deposit, Earnings per Share (EPS), Return on Assets (ROA) and Return on Equity (ROE). The list of selected banks is given below:

- $\quad$ Al- Arafah Islami Bank Limited (AIBL)

- $\quad$ EXIM Bank Limited (EXIMBL)

- Islami Bank Bangladesh Limited (IBBL)

- Shahjalal Islami Bank Limited (SJIBL)

- Social Islami Bank Limited (SIBL)

- First Security Islami Bank Limited (FSIBL) 
Researcher collected the secondary data from annual reports of the banks, journals and books. The ratios used in this study are:

Earnings per Share $($ EPS $)=\frac{\text { Earnings avialable to common shareholders }}{\text { No.of common share outstanding }}$

Return on Asset $(\mathrm{ROA})=\frac{\text { Earnings avialable to common shareholders }}{\text { Average } \text { Total Asset }}$

Return on Equity $(\mathrm{ROE})=\frac{\text { Earnings avialable to common shareholders }}{\text { Average Shareholder Equity }}$

To analyze the trend of the variables straight line trend equation was used in the study. The equation is,

$$
\widehat{Y}=a+b x \text {. }
$$

Here, $\quad \widehat{Y}$ : Represents trend values to distinguish them from actual $Y$ values.

a: Represents Y intercept

b: Represents slope of the line

$\mathrm{x}$ : Represents time

The square of correlation coefficient $\left(\mathrm{r}^{2}\right)$ tests the 'goodness of fit' and it is between 0 and 1 . The greater the $r^{2}$ the greater the variation percentage of $Y$ explained by the regression model and the closer the $r^{2}$ to zero, the worse the fit.

\section{RESULT AND Discussion}

The growth pattern of investment, total asset, and deposit, EPS, ROA and ROE of the selected Islamic Banks during 2011 to 2015 reflected in table 1, 2, 3, 4, 5 and 6 respectively.

Table 1. Growth of Investment

\begin{tabular}{|c|c|c|c|c|c|}
\hline \multirow{2}{*}{ Name of The Bank } & \multicolumn{5}{|c|}{ Amount of Investment(million) } \\
\cline { 2 - 6 } & $\mathbf{2 0 1 1}$ & $\mathbf{2 0 1 2}$ & $\mathbf{2 0 1 3}$ & $\mathbf{2 0 1 4}$ & $\mathbf{2 0 1 5}$ \\
\hline Al- Arafah Islami Bank Limited & 81486.78 & 112161.67 & 132854.33 & 155861.26 & 171354.28 \\
\hline Growth & & $36.64 \%$ & $18.45 \%$ & $17.32 \%$ & $9.94 \%$ \\
\hline EXIM Bank Limited & 107588.05 & 129705.45 & 156445.56 & 180723.12 & 215118.19 \\
\hline Growth & & $20.56 \%$ & $20.62 \%$ & $15.52 \%$ & $19.03 \%$ \\
\hline Islami Bank Bangladesh Limited & 321643.36 & 398480.79 & 469093.76 & 560062.87 & 623501.59 \\
\hline Growth & & $23.89 \%$ & $17.72 \%$ & $19.39 \%$ & $11.33 \%$ \\
\hline Shahjalal Islami Bank Limited & 87046.20 & 104898.60 & 97051.25 & 95302.91 & 107166.37 \\
\hline Growth & & $20.51 \%$ & $-7.48 \%$ & $-1.92 \%$ & $12.45 \%$ \\
\hline Social Islami Bank Limited & 57669.94 & 80688.99 & 92930.52 & 114143.69 & 141599.25 \\
\hline Growth & & $39.92 \%$ & $15.17 \%$ & $22.83 \%$ & 24.05 \\
\hline First Security Islami Bank Limited & 73511.92 & 101432.71 & 121597.02 & 162953.94 & 200579.94 \\
\hline Growth & & $37.98 \%$ & $19.88 \%$ & $34.01 \%$ & $23.09 \%$ \\
\hline
\end{tabular}

Source: Annual Report's data from 2011-2015 of Al- Arafah Islami Bank Limited, EXIM Bank Limited, Islami Bank Bangladesh Limited, Shahjalal Islami Bank Limited, Social Islami Bank Limited, First Security Islami Bank Limited

In table 1 it is observed that the growth rate of investment of all Islamic Banks was positive except Shahjalal Islami Bank Limited in 2013 and 2014. Among all the selected banks the highest growth rate of investment was in 2012 of Social Islami Bank Limited which was $39.92 \%$. At the same time Islami Bank Bangladesh Limited, Al- Arafah Islami Bank Limited, 
Shahjalal Islami Bank Limited and First Security Islami Bank Limited had the maximum growth in investment in 2012. EXIM Bank Limited experienced the highest growth rate of $20.62 \%$ in 2013.

Table 2. Growth of Total Asset

\begin{tabular}{|c|c|c|c|c|c|}
\hline \multirow{2}{*}{ Name of The Bank } & \multicolumn{5}{|c|}{ Amount of Total Asset } \\
\cline { 2 - 6 } & $\mathbf{2 0 1 1}$ & $\mathbf{2 0 1 2}$ & $\mathbf{2 0 1 3}$ & $\mathbf{2 0 1 4}$ & $\mathbf{2 0 1 5}$ \\
\hline Al- Arafah Islami Bank Limited & 106768.18 & 149320.36 & 143161.63 & 210439.01 & 229106.66 \\
\hline Growth & & $39.85 \%$ & $-4.12 \%$ & $46.99 \%$ & $8.87 \%$ \\
\hline EXIM Bank Limited & 129709.82 & 166997.93 & 195542.25 & 232833.95 & 265148.42 \\
\hline Growth & & $28.74 \%$ & $17.09 \%$ & $19.07 \%$ & $13.88 \%$ \\
\hline Islami Bank Bangladesh Limited & 389375.60 & 482649.49 & 546369.37 & 651579.48 & 725768.12 \\
\hline Growth & & $23.95 \%$ & $13.20 \%$ & $19.26 \%$ & $11.39 \%$ \\
\hline Shahjalal Islami Bank Limited & 107787.98 & 133900.02 & 130973.24 & 129532.46 & 141262.02 \\
\hline Growth & & $24.23 \%$ & $-2.19 \%$ & $-1.10 \%$ & $9.06 \%$ \\
\hline Social Islami Bank Limited & 83961.65 & 114829.11 & 126401.39 & 153585.31 & 180008.65 \\
\hline Growth & & $36.76 \%$ & $10.08 \%$ & $21.50 \%$ & $17.20 \%$ \\
\hline First Security Islami Bank Limited & 91012.90 & 129937.81 & 162033.22 & 204876.46 & 256604.94 \\
\hline Growth & & $42.77 \%$ & $24.70 \%$ & $26.44 \%$ & $25.25 \%$ \\
\hline
\end{tabular}

Source: Annual Reports (2011-2015)

Table 2 shows that the Islami Bank Bangladesh Limited had highest total asset during that period. Most of the banks experienced positive growth in total asset except Al-Arafah Islami Bank Limited in 2013 and Shahjalal Islami Bank Limited in 2013 and 2014. But in 2014 AlArafah Islami Bank Limited had highest growth in total asset and the growth rate was $46.99 \%$. The second highest growth was of First Security Islami Bank Limited in 2012. All other banks had the maximum percentage of growth in assets in 2012.

Table 3. Growth of Deposits

\begin{tabular}{|c|c|c|c|c|c|}
\hline \multirow{2}{*}{ Name of The Bank } & \multicolumn{5}{|c|}{ Amount of Deposits (Million) } \\
\cline { 2 - 6 } & $\mathbf{2 0 1 1}$ & $\mathbf{2 0 1 2}$ & $\mathbf{2 0 1 3}$ & $\mathbf{2 0 1 4}$ & $\mathbf{2 0 1 5}$ \\
\hline Al- Arafah Islami Bank Limited & 82186.98 & 118683.39 & 140980.56 & 166851.17 & 169887.08 \\
\hline Growth & & $44.41 \%$ & $18.79 \%$ & $18.35 \%$ & $1.82 \%$ \\
\hline EXIM Bank Limited & 107515.30 & 140025.42 & 165391.58 & 200009.00 & 224770.89 \\
\hline Growth & & $30.24 \%$ & $18.12 \%$ & $20.93 \%$ & $12.38 \%$ \\
\hline Islami Bank Bangladesh Limited & 341855.26 & 417845.69 & 472121.97 & 559713.58 & 614877.27 \\
\hline Growth & & $22.23 \%$ & $12.99 \%$ & $18.55 \%$ & $9.86 \%$ \\
\hline Shahjalal Islami Bank Limited & 82404.34 & 101366.80 & 96140.77 & 98443.33 & 109106.79 \\
\hline Growth & & $23.01 \%$ & $-5.16 \%$ & $2.39 \%$ & $10.83 \%$ \\
\hline Social Islami Bank Limited & 66461.72 & 93276.84 & 101842.17 & 124265.07 & 149511.88 \\
\hline Growth & & $40.35 \%$ & $9.18 \%$ & $22.02 \%$ & $20.32 \%$ \\
\hline First Security Islami Bank Limited & 78145.05 & 109905.57 & 139503.93 & 182503.18 & 231259.39 \\
\hline Growth & & $40.64 \%$ & $26.93 \%$ & $30.82 \%$ & $26.72 \%$ \\
\hline
\end{tabular}

Source: Annual Reports (2011-2015)

From table 3 it is observed that the Islami Banks attracted more customers and increase total deposit during that period without one exception of Shahjalal Islami Bank Limited in 2013. The selected banks had done better at raising total deposit in 2012. But the highest percentage of growth in deposit was experienced by Al-Arafah Islami bank Limited in 2012 among all the banks. Al- Arafah Islami Bank Limited, EXIM Bank Limited, Islami Bank 
Bangladesh Limited and First Security Islami Bank Limited had the lowest growth in 2015 whereas Social Islami Bank Limited had the lowest growth in 2013.

Table 4. Growth of EPS

\begin{tabular}{|c|c|c|c|c|c|}
\hline \multirow{2}{*}{ Name of The Bank } & \multicolumn{5}{|c|}{ Amount of EPS } \\
\cline { 2 - 6 } & $\mathbf{2 0 1 1}$ & $\mathbf{2 0 1 2}$ & $\mathbf{2 0 1 3}$ & $\mathbf{2 0 1 4}$ & $\mathbf{2 0 1 5}$ \\
\hline Al- Arafah Islami Bank Limited & 2.79 & 2.38 & 2.16 & 2.20 & 2.36 \\
\hline Growth & & $-14.70 \%$ & $-9.24 \%$ & $1.85 \%$ & $7.27 \%$ \\
\hline EXIM Bank Limited & 1.92 & 1.98 & 1.47 & 1.92 & 1.48 \\
\hline Growth & & $3.13 \%$ & $-25.76 \%$ & $30.61 \%$ & $-22.92 \%$ \\
\hline Islami Bank Bangladesh Limited & 3.70 & 4.49 & 3.12 & 2.46 & 1.96 \\
\hline Growth & & $21.35 \%$ & $-30.51 \%$ & $-21.15 \%$ & $-20.33 \%$ \\
\hline Shahjalal Islami Bank Limited & 2.10 & 3.13 & 1.78 & 1.02 & 1.79 \\
\hline Growth & & $49.05 \%$ & $-43.13 \%$ & $-42.70 \%$ & $75.49 \%$ \\
\hline Social Islami Bank Limited & 1.72 & 2.29 & 1.78 & 2.74 & 2.91 \\
\hline Growth & & $33.14 \%$ & $-22.27 \%$ & $53.93 \%$ & $6.20 \%$ \\
\hline First Security Islami Bank Limited & 1.71 & 1.85 & 1.89 & 1.02 & 1.26 \\
\hline Growth & & $8.19 \%$ & $2.16 \%$ & $-46.03 \%$ & $23.53 \%$ \\
\hline
\end{tabular}

Source: Annual Reports (2011-2015)

Table 4 concludes that all the selected Islamic Banks experienced negative growth rate in EPS in at least one year. Highest growth rate of EPS was of Shahjalal Islami Bank Limited in 2015. Al- Arafah Islami Bank Limited had the greatest growth rate of $7.27 \%$ in 2015 and EXIM Bank Limited had the greatest growth of $30.61 \%$ in 2014 . On the other hand Islami Bank Bangladesh Limited experienced the maximum growth in 2012 but the most negative growth of $-30.51 \%$ came in 2013. The highest growth rate of EPS of First Security Islami Bank Limited was in 2015 and Social Islami Bank Limited was in 2014.

Table 5. Growth of ROA

\begin{tabular}{|c|c|c|c|c|c|}
\hline \multirow{2}{*}{ Name of The Bank } & \multicolumn{5}{|c|}{ Percentage of ROA } \\
\cline { 2 - 6 } & $\mathbf{2 0 1 1}$ & $\mathbf{2 0 1 2}$ & $\mathbf{2 0 1 3}$ & $\mathbf{2 0 1 4}$ & $\mathbf{2 0 1 5}$ \\
\hline Al- Arafah Islami Bank Limited & 2.43 & 1.52 & 1.41 & 1.21 & 1.12 \\
\hline Growth & & $-37.45 \%$ & $-7.24 \%$ & $-14.18 \%$ & $-7.44 \%$ \\
\hline EXIM Bank Limited & 1.66 & 1.40 & 1.04 & 1.15 & 0.84 \\
\hline Growth & & $-15.66 \%$ & $-25.71 \%$ & $10.58 \%$ & $-26.96 \%$ \\
\hline Islami Bank Bangladesh Limited & 1.29 & 1.29 & 0.98 & 0.66 & 0.48 \\
\hline Growth & & $0.00 \%$ & $-24.03 \%$ & $-32.65 \%$ & $-27.27 \%$ \\
\hline Shahjalal Islami Bank Limited & 1.38 & 1.45 & 0.98 & 0.57 & 0.98 \\
\hline Growth & & $5.07 \%$ & $-32.41 \%$ & $-41.84 \%$ & $71.93 \%$ \\
\hline Social Islami Bank Limited & 1.50 & 1.48 & 1.04 & 1.38 & 1.23 \\
\hline Growth & & $-1.33 \%$ & $-29.73 \%$ & $32.69 \%$ & $-10.87 \%$ \\
\hline First Security Islami Bank Limited & 0.75 & 0.69 & 0.53 & 0.38 & 0.37 \\
\hline Growth & & $-8.00 \%$ & $-23.19 \%$ & $-28.30 \%$ & $-2.63 \%$ \\
\hline
\end{tabular}

Source: Annual Reports (2011-2015)

Growth in ROA of the banks is shown in Table 5.All the selected banks had experienced negative growth of ROA in most of the years. It indicates that the profitability of the banks was decreasing during the period. Al-Arafah Islami Bank Limited had highest ROA in 2011. Later on its ROA decreased every year. EXIM Bank Limited had highest growth rate of ROA in 2014. Islami Bank Bangladesh Limited had the same ROA in 2011 and 2012. Social Islami Bank Limited experienced the highest growth in 2014 whereas Shahjalal Islami Bank Limited experienced the highest growth in 2015. 
Table 6. Growth of ROE

\begin{tabular}{|c|c|c|c|c|c|}
\hline \multirow{2}{*}{ Name of The Bank } & \multicolumn{5}{|c|}{ Percentage of ROE } \\
\cline { 2 - 6 } & $\mathbf{2 0 1 1}$ & $\mathbf{2 0 1 2}$ & $\mathbf{2 0 1 3}$ & $\mathbf{2 0 1 4}$ & $\mathbf{2 0 1 5}$ \\
\hline Al- Arafah Islami Bank Limited & 20.19 & 14.94 & 15.11 & 13.58 & 25.72 \\
\hline Growth & & $-26.00 \%$ & $1.14 \%$ & $-10.13 \%$ & $89.40 \%$ \\
\hline EXIM Bank Limited & 14.99 & 13.43 & 10.18 & 11.34 & 8.68 \\
\hline Growth & & $-10.41 \%$ & $-24.20 \%$ & $11.39 \%$ & $-23.46 \%$ \\
\hline Islami Bank Bangladesh Limited & 18.10 & 16.70 & 12.06 & 8.78 & 6.71 \\
\hline Growth & & $-7.73 \%$ & $-27.78 \%$ & $-27.20 \%$ & $-23.58 \%$ \\
\hline Shahjalal Islami Bank Limited & 17.59 & 19.87 & 12.66 & 6.60 & 11.01 \\
\hline Growth & & $12.96 \%$ & $-36.29 \%$ & $-47.87 \%$ & $66.82 \%$ \\
\hline Social Islami Bank Limited & 15.23 & 15.02 & 11.79 & 16.58 & 16.29 \\
\hline Growth & & $-1.38 \%$ & $-21.50 \%$ & $40.63 \%$ & $-1.75 \%$ \\
\hline First Security Islami Bank Limited & 13.78 & 15.01 & 12.83 & 9.37 & 9.45 \\
\hline Growth & & $8.93 \%$ & $-14.52 \%$ & $-26.97 \%$ & $0.85 \%$ \\
\hline
\end{tabular}

Source: Annual Reports (2011-2015)

It is observed from table 6 that the growth of ROE of the banks was not satisfactory. In 2011 their condition was much better than in 2015. Al- Arafah Islami Bank Limited had the maximum growth percentage in 2015 and the minimum percentage in 2012. EXIM Bank Limited had only positive growth of $11.39 \%$ in 2014 . Shahjalal Islami Bank Limited had the highest ROE in 2012 but the maximum growth was in 2015. Social Islami Bank Limited experienced the greatest growth in 2014 whereas First Security Islami Bank Limited had the highest ROE in 2012.

Table 7. Trend analysis of the Islamic Banks.

\begin{tabular}{|c|c|c|c|c|c|c|c|}
\hline & & AIBL & EXIMBL & IBBL & SJIBL & SIBL & FSIBL \\
\hline \multirow[t]{2}{*}{ Investment } & $\widehat{Y}=a+b x$ & $\begin{array}{r}63713.29+ \\
22343.46 x\end{array}$ & $\begin{array}{r}78092.69+ \\
26607.80 x\end{array}$ & $\begin{array}{r}244966.91+ \\
76529.85 x\end{array}$ & $\begin{array}{r}89099.67+ \\
3064.47 x\end{array}$ & $\begin{array}{r}37012.48+ \\
20131.33 \mathrm{x}\end{array}$ & $\begin{array}{r}37317.93+ \\
31565.73 x\end{array}$ \\
\hline & $\mathrm{r}^{2}$ & 0.99 & 0.99 & 0.99 & 0.36 & 0.98 & 0.98 \\
\hline \multirow[t]{2}{*}{ Total Asset } & $\widehat{Y}=a+b x$ & $\begin{array}{r}76020.49+ \\
30579.56 x\end{array}$ & $\begin{array}{r}97032.51+ \\
33671.32 x\end{array}$ & $\begin{array}{r}306633.90+ \\
84171.50 x\end{array}$ & $\begin{array}{c}109916.99+ \\
6258.05 x\end{array}$ & $\begin{array}{r}62502.16+ \\
23085.02 x\end{array}$ & $\begin{array}{r}47056.25+ \\
40612.27 x\end{array}$ \\
\hline & $r^{2}$ & 0.91 & 0.99 & 0.99 & 0.62 & 0.98 & 0.99 \\
\hline \multirow[t]{2}{*}{ Deposit } & $\widehat{Y}=a+b x$ & $\begin{array}{r}68647.44+ \\
22356.80 x\end{array}$ & $\begin{array}{r}79194.01+ \\
29449.48 x\end{array}$ & $\begin{array}{r}274909.18+ \\
68791.19 x\end{array}$ & $\begin{array}{r}82347.98+ \\
5048.14 x\end{array}$ & $\begin{array}{r}47944.97+ \\
19708.86 x\end{array}$ & $\begin{array}{r}34615.54+ \\
37882.63 x\end{array}$ \\
\hline & $\mathrm{r}^{2}$ & 0.94 & 0.99 & 0.99 & 0.67 & 0.98 & 0.98 \\
\hline \multirow{2}{*}{ EPS } & $\widehat{Y}=a+b x$ & $2.69-0.10 x$ & $2.04-0.09 x$ & $4.80-0.55 x$ & $2.78-0.27 x$ & $1.44+0.28 x$ & $2.07-0.17 x$ \\
\hline & $r^{2}$ & 0.43 & 0.34 & 0.76 & 0.32 & 0.68 & 0.50 \\
\hline \multirow{2}{*}{ ROA } & $\widehat{Y}=a+b x$ & $2.42-0.29 x$ & $1.79-0.19 x$ & $1.62-0.23 x$ & $1.58-0.17 x$ & $1.52-0.06 x$ & $0.87-0.11 x$ \\
\hline & $\mathrm{r}^{2}$ & 0.78 & 0.88 & 0.56 & 0.94 & 0.27 & 0.94 \\
\hline \multirow{2}{*}{$\mathrm{ROE}$} & $\widehat{Y}=a+b x$ & $15.00+0.97 x$ & $16.14-1.47 x$ & $21.68-3.07 x$ & $21.48-2.64 x$ & $13.88+0.37 x$ & $16.38-1.43 x$ \\
\hline & $\mathrm{r}^{2}$ & 0.09 & 0.85 & 0.62 & 0.97 & 0.09 & 0.77 \\
\hline
\end{tabular}

The summary of trend equation and $r^{2}$ of investment, total asset, deposit, EPS, ROA and ROE of the six selected Islamic banks of Bangladesh is presented in table 7. The $r^{2}$ of investment of all the banks were above 0.90 and goodness of fit except Shahjalal Islami Bank Limited as it had a $\mathrm{r}^{2}$ of 0.36 . The trend equations of total asset for all the banks were positive and the $r^{2}$ of total asset of all banks was above 0.50 and in most cases above 0.90 . That is all banks have high potential to expand its bank size. The trend equations of deposit 
were positive and goodness of fit for all the banks as $r^{2}$ of deposit was above 0.50. Only Islami Bank Bangladesh Limited and Social Islami Bank Limited had $r^{2}$ of EPS was above 0.50. First Security Islami Bank Limited had $r 2$ of 0.50 . But the remaining banks' $r^{2}$ of EPS was not satisfactory. The $\mathrm{r}^{2}$ of ROA was above 0.50 for all banks except Social Islami Bank Limited. The trend equation of ROE of Al-Arafah Islami Bank Limited and Social Islami Bank Limited was positive but $r^{2}$ is less than 0.50. Except these two banks all the banks had $r^{2}$ which is greater than 0.50 . The $r^{2}$ of the selected variables in most cases were above 0.50 which indicates the Islamic Banks have great prospect in Bangladesh.

\section{CONCLUSION}

Banks have direct financial effect on the economy of a country. This study examined the performance of some selected Islamic banks by calculating the growth rate of some performance indicating variables and then estimating the trend lines of the variables. The growth of investment, total asset and deposit was positive of most of the Banks but the growth of EPS, ROA and ROE was not satisfactory. This indicates that the profit after tax of most of the banks was not increasing with increased total asset and share. But Islamic bank have great potential to improve services as well as net profit as they are continuously increasing total asset, collecting more deposits and spread investments.

\section{REFERENCES}

Abduh, M., Hasan, S. and Pananjung, A. (2013), "Efficiency and performance of Islamic banks in Bangladesh", Journal of Islamic Banking and Finance, vol. 30, no. 2, pp. 94-106.

Ahsan, M. K. (2016), "Measuring financial performance based on CAMEL: A study on selected Islamic Banks in Bangladesh", Asian Business Review, vol. 6, no. 13, pp. 47-56.

Akhter, W., Raza, A., Orangzab, and Akram, M. (2011), “Efficient and performance of Islamic banking: the case of Pakistan", Far East Journal of Psychology and Business, vol. 2, no. 2, pp. 54-70.

Chakraborty, J., Salam, F. and Rabbany, M. G. (2015), “Financial performance analysis of Islamic Banks in Bangladesh: A case study on Islami Bank Bangladesh Limited (IBBL)", International Journal of Economics, Finance and Management Sciences, vol. 3, no. 2, pp. 99-106.

Islam, M. S. and Salim, M. (2011), "Analysis of the operational efficiency of commercial banks: A study of the Islamic Banks in Bangladesh", Journal of Banking \& Services, vol. 5, no. 1, pp. 83-96.

Kabir, M. R., Ullah, M. H. and Khan, M. M. (2012), "Comparative analysis of profit trade of Islamic banks on investment (ROI) and fixed rate of interest on loan of Conventional banks in Bangladesh", World Journal of Social Sciences, vol. 2, no. 6, pp. 39-48.

Rashid, M. and Nishat, A. (2009), "Disparity of performance indicators of Islamic banks: Study on Bangladesh", International Journal of Business and Management, vol. 4, no. 8, pp. 52-72.

Uddin, M. H. (2014), "Measuring the performance of Islamic banks in Bangladesh: An exploratory study", International Journal of Ethics in Social Sciences, vol. 2 no. 1, pp. 73-94.

Yousuf, S., Islam, M. A., and Islam, M. R. (2014), "Islamic Banking Scenario of Bangladesh", Journal of Islamic Banking and Finance, vol. 2, no. 1, pp. 23-29. 


\section{(c) $(1)(9$ \\ BY No}

This Journal is licensed under a Creative Commons Attribution-NonCommercial 4.0 International License.

This license lets others remix, tweak, and build upon your work non-commercially, and although their new works must also acknowledge \& be non-commercial, they don't have to license their derivative works on the same terms. 